\title{
Z výskumu literatúry v Novom Sade
}

\author{
Viera Žemberová (Prešov)
}

\begin{abstract}
Abstrakt
Posledné desat'ročia venujú slovenská literárna veda a kultúrna publicistika pozornost' po slovensky písanej literatúre mimo územia Slovenska. Týmto záujmom doplńa potrebné poznanie o kultúre a tvorivosti Slovákov žijúcich mimo nášho územia, ktorí si udržiavajú jazykom kontakt s územím svojich predkov. K silným zázemiam slovenského jazyka, literárnej tvorby a výskumu patrí univerzitné prostredie v Novom Sade, kde pôsobí Jarmila Hodoličová. Príspevok sa sústredil na jej literárnovedné práce o tvorbe pre mladých čitatel'ov a o slovenskom kultúrnom zázemí vo Vojvodine.
\end{abstract}

\section{Klúčové slová}

archívny materiál; literárna história; jazykový kontext; kultúrna tradícia

\section{Abstract \\ From Research Literature for Young Readers in Novy Sad}

For the last decades, Slovak literary science and cultural journalism have been paying attention to Slovak literary literature outside Slovakia. This interest complements the necessary knowledge of the culture and creativity of Slovaks living outside of our territory, who maintain their contact with the territory of their ancestors. The strong backgrounds of the Slovak language, literary creation and research include the university environment in Novom Sade, where Jarmila Hodoličová works. The contribution focused on her literary work on creation for young readers and on the Slovak cultural background in Vojvodina.

\section{Key words}

archive material; literary history; language context; cultural tradition 
Pôvodná, po slovensky písaná odborná a umelecká literatúra vo Vojvodine má prirodzenú stáročnú tradíciu kultivovania slovenčiny ako svojho jazyka, rovnako utvárané podmienky na existenciu a rozvíjanie sa, má pevné inštitucionálne a vzdelávacie zázemie, výrazné autorské osobnosti a má výstupy, ktoré sprevádza nielen pozornosṫ, ale aj uznanie odbornej a kultúrnej verejnosti.

Popri literárnom vedcovi Michalovi Harpáňovi ${ }^{1}$, spisovatelovi Palovi Bohušovi ${ }^{2}$, všestrannom Vítazoslavovi Hroncovi, ${ }^{3}$ kultúrnom publicistovi a vydavatelovi Miroslavovi Demákovi ${ }^{4}$ by bolo možné pripomenút si nemálo tvorivých osobností, ktoré do kontaktu slovakistika a slavistika vstupujú svojou kultúrnou aktivitou a za posledné tri desaṫročia rozvíjajú výrazne v iniciujúcom kultúrnom koncepte a v komunikačnom režime to, čím sa udržiava aktívne spoločenské a vzájomné prepojenie, v literárnovednom a literárnom súžití predovšetkým odbornú a vzdelávaciu spoluprácu aj informovanie o národnom či o medziliterárnom výskume.

Poznávací a komparatívny záujem o kultúru, literárny život aj umeleckú tvorbu Slovákov žijúcich mimo územia svojej historickej zeme zhodnocoval vyše dvoch desatročí Peter Andruška ${ }^{5}$ v náročnom výskumom projekte, ktorý obsiahol spravidla literárnohistoricky iniciované zábery do kultúrnej publicistiky, dostupného heuristického výskumu, prístupného kultúrneho a časopiseckého, textového a osobného autorského materiálu uchovaného a spracovaného vo vojvodinských archívoch. V devätdesiatych rokoch v ňom pokračoval tak, že zúžil šírku slovakistického materiálového výskumu a sústredil sa na zdroje spoločenského a kultúrneho významu viažuce sa na konkrétnu autorskú či výraznú kultúrnu osobnost', aby v záverečnej etape medziliterárne rozvinutého projektu sa Andruškov výskum zhmotňoval vo výnimočnej nitrianskej akademickej sérii Zošity s ústredným pomenovaním Kultúra a súčasnost’ v literárnohistoricky a v interpretačne komponovaných porovnávacích literárnovedných výstupoch. Medziliterárne poznávanie kultúrneho a literárneho života Slovákov žijúcich mimo svojej pôvodnej vlasti zásluhou Petra Andrušku a jeho spolupracovníkov prinieslo do dejín vzájomného utvárania et-

1 Michal Harpáň (1944), napr. jeho monografia Texty a kontexty. Slovenská literatúra a literatúra dolnozemských Slovákov. Bratislava: Literárne informačné centrum, 2004.

2 Pal’o Bohuš (1921-1997), vlastným menom Pavel Sabo; „významný básnik slovenskej menšiny v Srbsku“.

3 Vítazoslav Hronec (1944), básnik, prozaik, prekladatel', literárny vedec, spoluautor rozsiahleho projektu Medzi dvoma domami 1. Antológia slovenskej vojvodinskej poézie v zahraničí (2008); Medzi dvoma domami 2. Antológia slovenskej vojvodinskej prózy v zahraniči (2010); Medzi dvoma domami 3. Antológia slovenskej vojvodinskej eseje v zahraniči (2010).

4 Miroslav Demák (1948), napr. Medzi dvoma domovinami 1. Antológia slovenskej poézie v zahraniči (2008); Kúpim bonbón ako vráta. Výber zo slovenskej vojvodinskej poézie pre deti (1994); Lahko lietat', ked' máš krídla. Výber zo slovenskej vojvodinskej poézie pre deti (2008).

5 Peter Andruška (1943), prozaik, básnik, esejista, autor textov pre mladého čitatela, sa od začiatku devätdesiatych rokov intenzívne venoval výskumu po slovensky písanej literatúre v prostredí menšín na území Mad’arska a na Dolnej zemi. Projekt Kultúra a súčasnost'(2004) sa premenil na rad kolektívnych publikácií, ktoré sa sústredili na sondy do uchovaného či aktívneho kultúrneho a literárneho života potomkov Slovákov v juho- a južnoeurópskom priestore kontinentu. Z autorského výskumu publikoval práce Literárna tvorba Slovákov z Dolnej zeme (1994), Literárna tvorba národnostných menšin (2000), Dolnozemské podoby slovenskej kultúry (2007), Antológia slovenskej krajanskej poézie (2001) a početné materiálové a literárnohistoricky koncipované práce. 
nickej mapy posledných storočí nezamenitelný vklad, ktorý sa v súčasnosti profiluje ako štúdium široko otvoreného záberu do štyroch storočí kultúry dolnozemskej slovenskej menšiny.

Od devätdesiatych rokov 20. storočia sa záujem o slovenskú literatúru v zahraničí viazal na poslanie literárneho a kultúrneho pracovníka s jediným zámerom, emancipovat a dôkladne poznat' slovenskú literatúru žijúcu mimo autentického slovenského kultúrneho priestoru, čo sa stalo skutočnostou a vklady do literárnohistorického kontextu slovakistiky a slavistiky ostávajú neprehliadnutel’né, ba výskumne priam vyhl’adávané.

Pôvodný jednosmerne nastavený zámer poznat slovakistiku za hranicami slovenského kultúrneho pôdorysu sa metodologicky ustálil a výskumne aj kultúrne sa rozvíja ako intenzívna medziliterárna a etnická potreba povýšená na proces vzájomného dopĺñania sa a prepájania kultúrnej aj literárnovedne rozvíjanej tvorivej súčasnosti v tých zložkách slovenskej vojvodinskej kultúry a literatúry, ktoré uchovávajú svoju autenticitu a majú záujem o komparovanie aj hodnotenie s procesmi živými v slovenskej literatúre a literárnej vede. V literárnovednom podloží sa tak aktivizujú literárna história a literárna kritika z autentického vojvodinského slovakistického priestoru.

V Novom Sade má na univerzitnej pôde svoje pevné a reprezentatívne miesto oddelenie slovakistiky zložené zo štúdia slovenskej literatúry a slovenského jazyka a medzi erbové osobnosti v literárnovednom výskume patrí Michal Harpáň, ktorý svoje štúdiá vedie mnohorozmerne, ale výrazné úsilie venuje šíreniu vedeckého profilu slovenskej poézii vo Vojvodine.

Žáner monografie vyhovuje prístupu aj organizovaniu výstupov profilového výskumu konkrétnej prozaickej alebo básnickej osobnosti. Februárové dvojčíslo (5-6, 12. 2. 2014, s. 9) kultúrneho periodika Literárny týždenník zverejnil rozhovor Etely Farkašovej so Zuzanou Č́ížikovou, Harpáňovou študentkou a autorkou monografie o „poprednej predstavitel'ke dolnozemskej slovenskej literatúry“ s názvom Básnické dielo Viery Benkovej (2005). V rozhovore sa pripomenula rozpracovaná štúdia o Jánovi Labáthovi pod názvom Slovenská vojvodinská poézia v pozornosti literárnej vedy. Rozhovor, ktorý prirodzene smeroval od Zuzany Čížikovej ad fontes znova k jej osobnostnému profilu a potvrdil to, o čom už nemožno zapochybovat, že na Dolnej zemi sa nielen po predkoch uchovalo, ale jestvuje na výskum, poznanie, šírenie a zhodnocovanie vojvodinskej, po slovensky napísanej literatúre, slovami Z. Čížikovej, „široké pole na výskum, nielen literárnovedný, ale $i$ z aspektu kultúry, histórie [...]“. Pointou rozhovoru Etely Farkašovej a Zuzany Č́́žikovej sa stalo konštatovanie: „Ešte štastie, že je kontakt s materskou krajinou v poslednom obdobi živši a čulejši a že sa tým otvára možnost' lepšie sa naváajom spoznat', čo môže naše domovské literatúry len a len obohatit *. Toto želanie bude latentné, udržiavat ho v jeho aktuálnosti bude geografický a literárny priestor, dejinami vytvorený rozostup v kultúrnej pamäti, ale aj skutočnost', že vojvodinská slovakistka žije v súručenstve s d’alšou autentickou národnou literatúrou a ich vzájomný kultúrny a výskumný dotyk musí byt prítomný a mal by prirodzene byt v pôvodnej tvorbe vojvodinskej slovenskej literatúry.

Výskumné adaptovanie vojvodinskej tvorby pre mladých čitatelov do vývinového celku slovenskej literatúry pre deti a slovenskej literatúry pre mládež uskutočnila v syntéze Dejiny slovenskej literatúry pre deti a mládež od roku 1960, ktoré sa pripravili pod odbornou gesciou 
Zuzany Stanislavovej ${ }^{6}$, do ktorej prizvala Jarmilu Hodoličovú z univerzity v Novom Sade za spoluautorku, popri d’alších so zámerom rekonštruovat’ zázemie, teda kto a čo píše a čo čítajú deti vo vojvodinskom „kraji“. Pozvanie vyslala editorka správnej adresátke, Jarmila Hodoličová7 vo svojej literárnovednej genéze má vpísaný materiálový výskum oficiálnych aj súkromných archívov, časopisov, edícií, spisovatelov i „pismákov“ a textovej tvorby, ktorá vyšla na Dolnej zemi pre slovenské deti a čitatelov spred troch storočí po súčasnost'.

Literárna historička Jarmila Hodoličová si svoje miesto v literárnovednom výskume utvárala cez detskú literatúru, ktorú výskumne uzavrela vo výstupe Prehl'ad dejín slovenskej vojuodinskej prózy pre deti (2005) a začína ho sledovat prostredníctvom autorských portrétov od 18. storočia, aby ho nateraz uzavrela reprezentatívnym výberom rozprávok Medovnik. Chrestomatia slovenskej vojvodinskej literatúry pre deti (2011), ktorú autorsky sama dotvára prehladovou kapitolou Slovenská vojvodinská literatúre pre deti. Literárnohistoricky svoje poznanie materiálu rozložila do chronologického prierezu od 18. storočia až po súčasnoste. Vývinový proces sledujú podkapitoly o literatúre v znamení spomienok na národnooslobodzovací boj a pohlad do nových dní - šesṫdesiate roky, na najplodnejšie obdobie literatúry pre deti a mládež - sedemdesiate roky, na najchudobnejšie obdobie - devätdesiate roky a na literatúru v rokoch 2000-2010. Literárnovedný život v súčasnosti, podla autorky, okrem jej výstupov dotvára práca Pavla Mučaja Podl’a duše dietata (2005), v nej sleduje recepčné kontakty slovenskej a vojvodinskej tvorby pre mladých čitatelov.

V publikácii Kontúry slovenskej vojvodinskej literatúry a kultúry (2011) rozširuje Jarmila Hodoličová javové a problémové podložie svojho výskumu, pritom metodicky nemení postup práce s dokumentom: identifikácia materiálu, autorské mapovanie, porozumenie textu, interpretácia textu, naznačenie spoločenských a hodnotových väzieb do širšieho kultúrneho priestoru a iného slovanského jazykového kódu. Tematické a kompozičné rozčlenenie publikácie zodpovedá dominantnému substantívu v názve publikácie: kontúry. Autorka vytvára predovšetkým časové vymedzenie a náčrty súvislostí objasňovaného artefaktu, pointuje svoje vymedzenia pre širšie vývinové súvislosti, naznačuje personálne či inak vytvorené kultúrne kontakty, medzi nimi zvýrazňuje odlišnosti a presuny v rámci dominantného etnického spoločenstva pre vojvodinských Slovákov, ktorí svoju jazykovú identitu nenavrstvujú uzavretostou svojho prostredia, ale uvedomovaným napájaním sa a postupným utváraním iniciačných väzieb na kultúru, do ktorej vstupujú a dorozumievajú sa s ňou spoločnou látkou, emóciami, mravmi a hodnotami. Výskumná ambícia Jarmily Hodoličovej naisto smeruje k naplneniu profesijného želania, vytvorit celostný profil dejín vojvodinskej slovenskej literatúry vo všetkých jej súradniciach a osobitostiach.

Monografické a portrétne štúdie vznikli z biografických a bibliografických poznatkov o Albetovi Martišovi, Gustávovi Maršallovi-Petrovskému, o spisovatel’skom rode Čajakovcov a o vztahoch Svetozár Hurbana Vajanského k vojvodinskému prostrediu. Tento vývi-

6 STANISLAVOVÁ, Zuzana a kolektív: Dejiny slovenskej literatúry pre deti a mládež od roku 1960. Bratislava: Literárne informačné centrum, 2011.

7 Jarmila Hodoličová (1952), pozri jej štúdiu Pôvodná literárna tvorba pre deti a mládež vojvodinských Slovákov v rokoch 1996-2015 (bilancia). Slovenská literatúra 63, 2016, č. 4, s. 287-297. 
nový blok zasahuje latentne od 18. storočia až po začiatok 20. storočia aj v učebniciach dejín slovenskej literatúry a vypovedá, popri inom, aj o jave dvojdomost' autora a o tej iste na viacero podnetov reagujúcej náučnej, hodnotovej a ideovej dispozícii jeho tvorby, čo je možné iba tak, že sa vývinovo docení a hodnotovo objektívne interpretuje dosah i presah reálií politicko-geografického rozloženia slovanského etického prvku v európskom kultúrnom a umelecky tvorivom zemepise.

Slovenské ženské hnutie na prelome dvoch storočí má v slovenskej literatúre dominantné osobnosti v činoch a postojoch ranej ženskej aktivity v slovenských národných dejoch v Terézii Vansovej, Eleny Maróthy Šoltésovej a zahrnuje do seba dnes už klasický fond tvorby realistických spisovateliek. V historicko-interpretačnom výklade Jarmily Hodoličovej ide o vytvorenie panoramatického pohladu zasahujúceho kultúrnu sietnicu prebúdzania, formovania a podnecovania národného života, ktorý si našiel aj tematické vyjadrenie v žánroch epiky. Po exkurze do nástrojov, ktoré sa zúčastnili v minulosti na formovaní Vzdelávania v slovenskom jazyku vo Vojvodine, pritom sa dôraz kladie na čítankové učebnice až po rok 2010, nasleduje náročnejšia osvetovo-kultúrna publikácia Národný kalendár a časopis Nový život v časti Slovenské periodiká vo Vojvodine. V slovenskej literárnovednej obci si zvýšenú pozornost’ získalo periodikum Nový čas, svoju odbornú hodnotu si utváralo príspevkami sústredenými na genologickú problematiku, otázky teórie textu, ale zamýšlalo sa aj nad príjemcom umeleckej literatúry, teda vytváralo priestor aj na relevantnú literárnu kritiku. V Sondách do našej literárnej kritiky sa stretli tri historicko-kritické marginálie dedikované obnovenému vydaniu románu Jána Čajaka Zuzka Turanová, prierezu prózami Zoroslava Speváka a jubilejnej reminiscencii na publikované literárnohistorické práce Jána Kmet̉a. Záver publikácie patrí východisku Hodoličovej záujmu o literatúru a literárnovednú reflexiu nad získaným materiálom a textom, zvláštnu pozornost' venuje literatúre pre mladého čitatel’a. Miera reminiscencie je v tomto bloku vysoká a zbližuje sa s rekapituláciou toho, čo Jarmila Hodoličová publikovala o tejto recepčnej línii v doterajšom svojom sondovaní vo vojvodinskej slovenskej literatúre.

Prítomnost' slovenskej literatúry a kultúry vo Vojvodine rekapitulovala Jarmila Hodoličová na medzinárodnej konferencii Slovensko-srbské literárne a kultúrne prieniky ${ }^{8}$ mapovaním Pôvodnej literárnej tvorby pre deti a mládeže vojvodinských Slovákov v rokoch 1996-2015 (bilancia). Záujem o literatúru pre detského čitatel'a sa vymedzuje periodizačne ako pôsobenie "generácie spisovatel’ov sedemdesiatych rokov" "9. O desat'ročie neskôr (Ján Labáth, 1983) tvorba pre detského čitatela zohráva rolu reprezentanta po slovensky písanej umeleckej spisby vo vojvodinskom literárnom a kultúrnom živote. Jarmila Hodoličová syntetizuje produkciu a jej spoločenskú reflexiu v práci Prehl’ad dejin slovenskej vojvodinskej prózy pre deti ${ }^{10}$. Produkciu rokov 1996 až 2015 autorka mapuje v genologickom

8 HODOLIČOVÁ, Jarmila: Pôvodná literárna tvorba pre deti a mládež vojvodinských Slovákov v rokoch 1996 2015 (bilancia). Slovenská literatúra 63, 2016, č. 4, s. 287-297. Prednesené na medzinárodnej konferencii organizovanej Ústavom slovenskej literatúry SAV v Bratislave 29. 9. 2016.

9 Do generácie autorov pre detského čitatel’a v sedemdesiatych rokoch minulého storočia, ktorá je autorsky „najpočetnejšia“ zarad’uje: Juraja Tušiaka, Michala Babínka, Pavla Grňa, Pavla Mučaja, Annu Majerovú a Vieru Benkovú. Pozri HODOLIČOVÁ, Jarmila: tamže, s. 287.

10 HODOLIČOVÁ, Jarmila: Prehlad dejin slovenskej vojvodinskej prózy pre deti. Beograd: Zavod za udžbenike 
priereze, ktorý začína Prózou pre deti, pokračuje Poéziou pre deti, Dramatickou tvorbou pre deti a mládež a končí Knihami o detoch a detskej literatúre. Čast', ktorá má názov Próza pre deti, začína autorka takto: „V polovici devätdesiatych rokov knižne debutovali autori novej generácie, ktorí do vtedy publikovali v časopise Zornička. Knihy Martina Prebudila (1960), Márie Kotvánovej-Jonášovej (1975) sú určené čitatelom od 11 do 15 rokov a charakterizuje ich úsilie pochopit' a podat’ opis súčasného života dietat'a" ${ }^{11}$. Okrem debutantov v próze pre mladých čitatel'ov do rekapitulácie zaradila J. Hodoličová prózu iniciovanú l’udovou rozprávkou tradíciou (Anna Šimáková), príbehy z rozpomienok na detstvo (Daniel Dudok), cestopisnú prózu (Andrej Čipkár), pripomína, že medzi čitatel’mi sú vyhl'adávané dobrodružné príbehy a nezabúda sa ani na zážitky z prírodného prostredia (Anna Kukučková). Zo žánrov sa presadila poviedka. Poézia pre deti „sa v porovnani s prózou už dlhši čas rozvíja menej“, konštatuje J. Hodoličová, autorsky taží z tvorby Pavla Mučaja a Juraja Tušiaka, ku ktorým sa pripájajú Juraj Bartoš a Daniel Pixiades, Mária Vršková a Anna Malková. Dramatická tvorba pre deti a mládež sa podla autorky spolieha na tvorbu Anny Nemogovej-Kolárovej a Eleny Hložanovej, ktoré žánrovo ponúkajú divadelné hry na rozhlasovú aj javiskovú realizáciu.

Vojvodinská slovenská literatúra a literárna veda sú prítomné, výrazné a svojou hodnotou vstupujú do nadnárodného kultúrneho priestoru. Aktivita kultúrneho a vedeckého života vojvodinských Slovákov sa spojila s akademickou ustanovizňou v Novom Sade, ktorá dbá o ich uchovanie, rozvíjanie a šírenie. Duchovný a kultúrny život vojvodinských Slovákov má široký záber. Ten spočíva v generáciách osobností, ale i v tom, že má výrazne ukotvenú a generáciami rešpektovanú kultúrnu tradíciu vyjadrenú svojím jazykom, ale predovšetkým tým, že svojou prítomnostou, osobnostami vedy a umenia, ale väčšmi v čase ukotvenú hodnotou svojej identity zatlačila do úzadia, ba viac, prekročila svojou kultúrou vymedzenie osamelej etnickej menšiny.

\section{prof. PhDr. Viera Žemberová, CSc.}

Inštitút slovakistiky a mediálnych štúdií

Filozofická fakulta, Prešovská univerzita v Prešove

Ul. 17. novembra 1, 08000 Prešov, Slovensko

viera.zemberova@unipo.sk

i nastavna sredstva, 2005. Informácia je prevzatá z Hodoličovej textu v Slovenskej literatúre 63, 2016, č. 4, z poznámky číslo 5 pod čiarou na s. 288.

11 Tamže, s. 289. 